\title{
Correlation Studies in Gladiolus
}

\author{
S. K. Patra ${ }^{1 *}$ and C. R. Mohanty ${ }^{2}$ \\ ${ }^{1}$ Department of Floriculture and Landscaping, College of Agriculture, \\ O.U.A.T., Bhubaneswar-751003, India \\ ${ }^{2}$ Department of plant breeding and genetics, College of Agriculture, \\ O.U.A.T., Bhubaneswar-751003, India \\ *Corresponding author
}

\section{A B S T R A C T}

\section{Keywords}

Correlation, florets, genotypes

Article Info

Accepted:

22 January 2019

Available Online:

10 February 2019
A study on association among various characters in 30 gladiolus genotypes revealed that significant positive association was noticed both at phenotypic and genotypic level for number of florets per spike with distance between two florets, number of florets remain open at a time and bloom life whereas length of spike had significant positive association with rachis length, number of floret per spike, distance between two florets and number of florets remain open at a time.

\section{Introduction}

Gladiolus, a member of the family Iridaceae and subfamily Ixoideae, is one of the most popular ornamental bulbous plants grown commercially in many parts of the world for its fascinating flowers with variety of colours, huge form of florets and good keeping quality. It stands fourth in the international cut flower trade after carnation, rose and chrysanthemum. The demand for new quality cultivar is ever increasing all over the world and this demand is seen in our country also. Every now and then, a superior cultivar replaces the existing one which is in many respects very similar to it. This is a continuous process and the demand for still better cultivars is there all the time. Besides, the cultivars lose their existence in the course of time. Thus, the situation demands to continuously breed new cultivars.

It is vital to have understanding of the association between the component characters and their relative contribution to economic yield (Length of spike, size of floret and number of florets per spike) to bring about a rational improvement in gladiolus in the desired direction. Correlation can show relative influence of various components on economic yield and contributing traits and indicate those characters upon which more emphasis should be given by the breeder during selection. 


\section{Materials and Methods}

The present investigation was carried out during the period from November to May 2010-11 and 2011-12 in form of field experiments at the Department of Floriculture and Landscaping, College of Agriculture, OUAT, Bhubaneswar. The experiment was laid out in RBD with three replications. The row to row and plant to plant spacing were maintained at $30 \mathrm{~cm} \times 20 \mathrm{~cm}$ respectively. Thirty genotype of gladiolus were collected from the Directorate of Horticulture, Government of Odisha, imported from Netherland used for the investigation. The experimental data were recorded on five randomly selected plants in each plot and subjected to variance and covariance analysis described by Panse and Sukhatme (1985). The correlation at phenotypic and genotypic levels between the pairs of characters were calculated from variance and covariance components as proposed by Al Jibouri et al., (1958).

\section{Results and Discussion}

Estimates of genotypic and phenotypic correlation coefficients for all 19 characters related to flower yield (length of spike \& number of florets/spike) provided useful information for choice of characters in selection programme.

Correlation coefficient analysis measures the mutual relationship between various plant characters and determines the component characters on which selection is based for genetic improvement for a particular character.

A positive correlation between desirable characters is favorable to the plant breeder because it helps in simultaneous improvement of both the characters. Correlation, studies at genotype level indicated that number of florets per spike was significantly and positively associated with distance between two florets $(0.701)$ and bloom life of spike $(0.704)$ at $1 \%$ level while it was significantly and positively associated with diameter of floret (0.472) and number of florets remain open at a time $(0.568)$ at $5 \%$ level of significance. Further positively correlated with length of floret (0.416) having nonsignificant values. Weight of corm (-0.285) and diameter of corm (- 0.293) were negatively correlated with this trait, but found non-significant. Highly significant positive correlation existed between length of spike and rachis length (0.854), as well as distance between two florets $(0.629)$ while significant positive correlation was observed with number of florets per spike (0.563), number of florets remain open at a time $(0.528)$ \& bloom life of spike (0.460). Further this trait exhibited a positive association with spike diameter (0.361), length of floret (0.081) \& diameter of floret $(0.111)$ while negatively associated with weight of corm (- 0.144) \& diameter of corm (-0.127) having nonsignificant values.

Phenotypic correlation, studies revealed that number of florets per spike was significantly and positively associated with distance between two florets (0.666) and bloom life of spike (0.682) at $1 \%$ level and number of florets remain open at a time $(0.525)$ at $5 \%$ level. Further positively correlated with length of floret (0.382) and diameter of floret (0.438) having non-significant values. Weight of corm (- 0.274) and diameter of corm (0.269 ) were negatively correlated with this trait, which had non-significant values. Significant and positive correlation existed between length of spike and rachis length (0.831), distance between two florets (0.589), number of florets per spike (0.553) and number of florets remain open at a time (0.491). 
Table.1 Genotypic correlations among 19 characters in 30 gladiolus genotypes

\begin{tabular}{|c|c|c|c|c|c|c|c|c|c|c|c|c|c|c|c|c|c|c|}
\hline Characters & 1 & 2 & 3 & 4 & 5 & 6 & 7 & 8 & 9 & 10 & 11 & 12 & 13 & 14 & 15 & 16 & 17 & 18 \\
\hline 2 & .073 & & & & & & & & & & & & & & & & & \\
\hline 3 & -.078 & .104 & & & & & & & & & & & & & & & & \\
\hline 4 & $.695^{* *}$ & .110 & .228 & & & & & & & & & & & & & & & \\
\hline 5 & .163 & .159 & .000 & .162 & & & & & & & & & & & & & & \\
\hline 6 & .331 & -.077 & -.227 & .258 & .062 & & & & & & & & & & & & & \\
\hline 7 & .295 & -.010 & -.202 & .240 & .131 & $.994^{* *}$ & & & & & & & & & & & & \\
\hline 8 & .268 & -.107 & -.224 & .203 & .080 & $.991^{* * *}$ & $.998^{* *}$ & & & & & & & & & & & \\
\hline 9 & .106 & .186 & .110 & .150 & .059 & .006 & .034 & -.005 & & & & & & & & & & \\
\hline 10 & .281 & $.552^{*}$ & -.114 & .382 & .284 & .055 & .102 & .030 & .361 & & & & & & & & & \\
\hline 11 & .046 & .117 & .047 & -.058 & .157 & -.038 & .030 & .005 & $.854^{* * *}$ & .341 & & & & & & & & \\
\hline 12 & .206 & .386 & -.021 & .043 & -.100 & .156 & .184 & .154 & $.563^{*}$ & .445 & .585 & & & & & & & \\
\hline 13 & .067 & .030 & .207 & .057 & .083 & .083 & .121 & .097 & .081 & .218 & .385 & .416 & & & & & & \\
\hline 14 & .148 & -.113 & .180 & .094 & -.047 & .171 & .157 & .159 & .111 & .167 & .363 & $.472^{*}$ & $.913^{* * *}$ & & & & & \\
\hline 15 & .237 & .243 & -.002 & .165 & -.113 & .237 & .225 & .202 & $.629^{* * *}$ & .158 & $.594^{* *}$ & $.701^{* *}$ & .278 & .283 & & & & \\
\hline 16 & .379 & $.466^{*}$ & -.116 & .177 & .215 & -.003 & .065 & .018 & $.528^{*}$ & .324 & $.593^{* *}$ & $.568^{*}$ & .336 & .301 & $.571^{*}$ & & & \\
\hline 17 & .108 & $.513^{*}$ & -.169 & -.031 & -.121 & -.054 & -.032 & -.072 & $.460^{*}$ & .450 & .398 & $.704^{* *}$ & .213 & .186 & $.635^{* * *}$ & $.595^{* *}$ & & \\
\hline 18 & -.106 & -.058 & -.010 & -.068 & .416 & .127 & .223 & .239 & -.144 & .025 & -.063 & -.285 & -.126 & -.201 & $-.479^{*}$ & -.185 & -.267 & \\
\hline 19 & -.109 & -.067 & -.061 & -.113 & .383 & -.327 & -.246 & -.220 & -.127 & -.107 & -.019 & -.293 & -.183 & -.196 & $-.494^{*}$ & -.012 & -.272 & $.507^{*}$ \\
\hline
\end{tabular}

$*$ and $* *$ indicates significance at $5 \%$ and $1 \%$ level respectively

1. Plant height $(\mathrm{cm})$

2. Girth $(\mathrm{cm})$

11. Rachis length $(\mathrm{cm})$

3. No. of leaves at spike emergence stage

12. No. of florets per spike

4. Leaf length $(\mathrm{cm})$

13. Length of floret $(\mathrm{cm})$

5. Leaf width $(\mathrm{cm})$

14. Diameter of floret $(\mathrm{cm})$

15. Distance between two florets $(\mathrm{cm})$

6. Days to emergence of flower spike

16. No. of florets remain open at a time

7. Days to show colour of basal floret

17. Bloom life of spike

8. Days to opening of basal floret

18. Weight of corm $(\mathrm{cm})$

9. Length of spike $(\mathrm{cm})$

19. Diameter of corm $(\mathrm{cm})$

10. Spike diameter $(\mathrm{cm})$ 
Table.2 Phenotypic correlations among 19 characters in 30 gladiolus genotypes

\begin{tabular}{|c|c|c|c|c|c|c|c|c|c|c|c|c|c|c|c|c|c|c|}
\hline Characters & 1 & 2 & 3 & 4 & 5 & 6 & 7 & 8 & 9 & 10 & 11 & 12 & 13 & 14 & 15 & 16 & 17 & 18 \\
\hline 2 & .072 & & & & & & & & & & & & & & & & & \\
\hline 3 & -.073 & .120 & & & & & & & & & & & & & & & & \\
\hline 4 & $.670^{* * *}$ & .089 & .194 & & & & & & & & & & & & & & & \\
\hline 5 & .141 & .151 & .014 & .138 & & & & & & & & & & & & & & \\
\hline 6 & .307 & -.074 & -.216 & .243 & .055 & & & & & & & & & & & & & \\
\hline 7 & .277 & -.010 & -.185 & .222 & .129 & $.970^{* * *}$ & & & & & & & & & & & & \\
\hline 8 & .257 & -.093 & -.213 & .194 & .078 & $.971^{* * *}$ & $.984^{* * *}$ & & & & & & & & & & & \\
\hline 9 & .111 & .154 & .100 & .150 & .046 & .000 & .033 & .001 & & & & & & & & & & \\
\hline 10 & .191 & .424 & -.070 & .278 & .237 & .038 & .075 & .024 & .266 & & & & & & & & & \\
\hline 11 & .050 & .096 & .047 & -.051 & .144 & -.042 & .028 & .001 & $.831^{* * *}$ & .244 & & & & & & & & \\
\hline 12 & .198 & .341 & -.014 & .045 & -.093 & .141 & .163 & .140 & $.553^{*}$ & .323 & $.581^{* *}$ & & & & & & & \\
\hline 13 & .055 & .014 & .163 & .062 & .074 & .089 & .118 & .102 & .081 & .169 & .361 & .382 & & & & & & \\
\hline 15 & .218 & .199 & -.002 & .157 & -.105 & .231 & .220 & .196 & $.589^{* *}$ & .126 & $.572^{* * *}$ & $.666^{* *}$ & .271 & .269 & & & & \\
\hline 16 & .351 & .390 & -.109 & .162 & .192 & .001 & .058 & .013 & $.491^{*}$ & .240 & $.554^{*}$ & $.525^{*}$ & .321 & .257 & $.545^{*}$ & & & \\
\hline 17 & .102 & .453 & -.152 & -.037 & -.111 & -.047 & -.030 & -.067 & .435 & .317 & .381 & $.682^{* *}$ & .194 & .179 & $.602^{* *}$ & $.547^{*}$ & & \\
\hline 18 & -.102 & -.056 & -.011 & -.059 & .393 & .118 & .206 & .226 & -.139 & .013 & -.060 & -.274 & -.121 & -.196 & $-.462^{*}$ & -.178 & -.258 & \\
\hline 19 & -.103 & -.056 & -.055 & -.119 & .357 & -306 & -.230 & -.209 & -.114 & -.073 & -.013 & -.269 & -.162 & -.176 & $-.459^{*}$ & -.007 & -.246 & $.486^{*}$ \\
\hline
\end{tabular}

$*$ and $* *$ indicates significance at $5 \%$ and $1 \%$ level respectively.

1. Plant height $(\mathrm{cm})$

2. Girth $(\mathrm{cm})$

11. Rachis length $(\mathrm{cm})$

3. No. of leaves at spike emergence stage

12. No. of florets per spike

4. Leaf length $(\mathrm{cm})$

5. Leaf width $(\mathrm{cm})$

13. Length of floret $(\mathrm{cm})$

14. Diameter of floret $(\mathrm{cm})$

15. Distance between two florets $(\mathrm{cm})$

6. Days to emergence of flower spike

16. No. of florets remain open at a time

7. Days to show colour of basal floret

17. Bloom life of spike

8. Days to opening of basal floret

18. Weight of corm $(\mathrm{cm})$

9. Length of spike $(\mathrm{cm})$

19. Diameter of corm $(\mathrm{cm})$

10. Spike diameter $(\mathrm{cm})$ 
Further this trait exhibited a positive association with spike diameter (0.266), length of floret (0.081), diameter of floret $(0.102)$ and bloom life of spike $(0.435)$ while it was negatively associated with weight of corm (- 0.139) and diameter of corm (- 0.114) having non-significant values.

In the present study, genotypic correlation coefficients were found to be higher than phenotypic correlation coefficients for most of the characters indicating a strong inherent association between various characters and were masked by environmental component with regard to phenotypic expression. Similar results were obtained by Balaram and Janakiram (2009), Kumar et al., (2011), Pal and Singh (2012) in gladiolus. Further exhibition of parallelism between the value of genotypic correlation coefficient and the phenotypic correlation coefficient, assured that there is not much influence of environment in determining the association of these characters which is probably due to a strong genetical makeup of the varieties.

Positive significant association between characters may be attributed either to pleotropic effect of single gene or due to location of two independent genes controlling these traits at close proximity (Janakiram and Rao, 1992). Wigan and Mather (1972) and Spraque (1966) also stated that a strong positive association of characters with yield may be attributed to linkage and pleotropy. In the present investigation significant positive correlation was noticed both at phenotypic and genotypic level for number of florets per spike with distance between two florets, number of florets remain open at a time and bloom life. It also exhibited significant and positive association of plant height with leaf length, length of spike with rachis length, number of florets per spike, distance between two florets, number of florets remain open at a time, rachis length with number of florets per spike, distance between two florets, number of florets remain open at a time, length of floret with diameter of floret, distance between two florets with number of florets remain open at a time, bloom life of spike, weight of corm with diameter of corm. This associations suggest that selection for component traits simultaneously will be effective in improving yield in gladiolus. In case of other pairs of characters showing significant negative correlation value and nonsignificant values either positive or negative at phenotypic and genotypic level have least importance for effective selection based on these characters. Similar findings were reported by Haussain et al., (2001) for number of florets per spike with duration of flowering, no of florets remain open at a time, rachis length and plant height, John et al., (2002) for spike length with plant height and florets per spike in gladiolus.

From the above result and discussion it may be suggested that distance between two florets, number of florets remain open at a time, bloom life, rachis length, length of floret and diameter of floret are the important correlated characters with yield in gladiolus i.e. number of florets per spike and spike length and simultaneous improvement in these traits will be helpful in gladiolus improvement programme.

\section{References}

Al-Jibouri, H.A., Miller, P.A. and Robinson, H.F. 1958. Genotypes and environmental variances and covariances in an upland cotton cross of inter specific origin. Agron. J. 50:633636.

Balaram, M., and Janakiram, T. 2009. Genetic variability in gladiolus genotypes for corm characters. J Ornam Hortic, 12(2): 123-126.

Hussain, C.T.S., Misra, R.L., Bhattacharjee, 
S.K. and Saini, H.C. 2001. Character association in gladiolus. $J$ Ornam Horticu, 4(1): 13-16.

Janakiram, T., and Rao, T.M. 1992. Genetic improvement of marigold. National Seminar on Commercial Floriculture in India present and potential: 35 .

John, A.Q., Bichoo, G.A. and Wani, S.A. 2002. Correlation studies in gladiolus. $J$ Ornam Hortic, New Series 1: 25-29.

Kuamr, J., Kumar, R. and Pal, K. 2011. Variability and character association in gladiolus (Gladiolus grandiflorus L.). Agricultural Science Digest - A Res J,
31(4): 280-284.

Pal, A., and Singh, R. 2012. Correlation and path coefficient analysis in gladiolus. Annals Hortic, 5(1): 103-107.

Panse, V.G., and Sukhatme, P.V. 1985. Statistical methods of Agricultural workers. Fourth Enlarged Edition, ICAR, New Delhi, 389p.

Spraque, G.F., 1966. Quantitative genetic in plant improvement in plant breeding. K.J. Frey (Edn.), pp.315-354.

Wigan, L.G., and Mather, K. 1972. Correlated response to the selection of polygenic characters. Ann. Eugenics, II: 354-364.

\section{How to cite this article:}

Patra S. K. and Mohanty C. R. 2019. Correlation Studies in Gladiolus. Int.J.Curr.Microbiol.App.Sci. 8(02): 3401-3406. doi: https://doi.org/10.20546/ijcmas.2019.802.396 